\title{
CLOVES syndrome
}

INSERM

\section{Source}

INSERM. (1999). Orphanet: an online rare disease and orphan drug data base. CLOVES syndrome. ORPHA:140944

CLOVE syndrome is characterized by Congenital Lipomatous Overgrowth, progressive, complex and mixed truncal Vascular malformations, and Epidermal nevi. 